\title{
DEVELOPING A BRAND ASSET MANAGEMENT STRATEGY IN TOURISTIC DOMAIN
}

\author{
Lecturer PhD Student Cristina Jinga, jinga_c@yahoo.com \\ “1 December 1918” University, Alba Iulia Romania
}

\begin{abstract}
With the groundwork laid in the first two phases, the next phase determines the right brand-based strategies to deliver on the brand vision's goals and objectives as well as the Brand Picture's market perceptions and perspectives. This phase draws on many traditional marketing tools such as positioning, pricing and channel strategies, but with a more strategic brand-oriented focus.
\end{abstract}

\subsection{Positioning Your Brand For Success}

The concept of „positioning” was launched by two advertising specialists, Al Ries and Jack Trout ${ }^{1}$. They considered it was a creative exercise made with an existing product. They defined positioning in the following manner: „Positioning is not about what you (the company) do with the product. Positioning refers to the way in which you influence the mentality of a potential buyer. That is, you position the product in the mind of the buyer."

For Kotler ${ }^{2}$, positioning is ,the act of projecting the offer and the image of a firm, in such a way that it occupies a distinct and appreciable place in the attention of the target buyers."

It is clear that both definitions emphasize the way in which the company wants to be perceived by the consumer, the essential idea being to determine him to identify himself with the respective brand. Positioning is in fact, the peak that the consumers assign to a brand and, in the same time, the peak the organisation chooses to occupy among the other existing ones.

The positioning may be emotional or rational. The emotional one tries to build an emotional relationship between the consumer and the product. The rational positioning is the one that offers a solution for the problems of the consumer, i.e ,this is your desire, and this is the solution I offer."

The one that transforms the product in a successful brand is the emotional positioning, for, as stated above, the use of rational elements makes the brand subject to comparison. In case a competitor enters the market offering the same advantages as the initial company, it is possible that the consumer turn to the new comer, due to the fact that it has no relationship with the first brand. On the other hand, emotions are not subject to measurement and the emotional bondage is more durable.

\subsubsection{The Positioning Strategy}

The consumer must have a clear reason to choose between brands. This reason is also called a competitive advantage of the chosen brand (it may be a price, quality, accessibility advantage). That's why - as first step in positioning - it is vital for the company to differentiate its offer from that of the competition.

${ }^{1}$ Cited by Philip Kotler in "The Managementul Of Marketing" 
${ }^{2}$ Kotler, Philip, ,,The Managementul of Marketing”

${ }^{3}$ idem

The diffentiation is the act of projecting a set of significant diffences with the scope of distinguishing the offer of a company from the one of its competition." - Philip Kotler. This is the moment when the company searches for a strong point, a diffentiation point that would clearly propel it above the competition.

These diffentiation points are effective if they meet the following criteria (Philip Kotler ${ }^{4}$ ):

- Are important (the advantages that result from these differentiation points are appreciated by a sufficient number of buyers),

- Are characteristic (either the differences are specific, or presented in a certain specific way),

- Are superior (from the point of view of obtaining the advantages),

- Can be communicated (to buyers),

- Represent something new (they cannot be easily copied by competition),

- Are accessible (the buyer can afford to pay for them),

- Are profitable (the companies consider their exploitation profitable).

It is clear that no product can be superior in all the 7 areas. That is why, according to the consumer category it addresses, the company must choose one or more differences to exploit and promote.

The companies will try to promote those few differences that will attract the most the attention of the target consumers. This is the second stage in positioning. We do not have a standard rule that the company should follow at this point. The opinions regarding the number of diffences that should be promoted vary a lot.

Positioning using only one advantage - there are specialists (Rosser Reeves ${ }^{5}$ ) who consider that a brand should emphasize just one advantage and concentrate on it, the respective brand being promovated as „number one" for that attribute. It is the case of the Porsche cars, well-known as leaders in the sports car industry or Mercedes known for their high technology. By promoting just one attribute, the brands are more easily enshrined in the minds of the consumers, because people tend to remember the number one in the domain.

Positioning using two or three advantages. The car industry provides another example: the Volvo cars are well-known for being the safest and most durable. In the same time, Beecham promotes the toothpaste Aquafresh as encompassing the three advantages: „cavity protection”, „fresh breath” and „,whiter teeth”.

The higher the number of the advantages, the bigger the number of customers the brand addresses. This is due to the fact that the positioning strategy attracts more categories of consumers. But in the same time, the higher the number of advantages the brand offers, it also increases the risk of confusion regarding the specific brand.

\footnotetext{
${ }^{4}$ Kotler, Philip, ,The Managementul of Marketing”

5 cited in Attig, D.Wendal, ,Blow The Whistle On Your Competition”, Florida, The Ampersand Publishing Group
} 


\subsubsection{Positioning Errors:}

- Underpositioning: many of the buyers have just a vague idea about the specific brand,

- Overpositioning: the buyers have a narrow image of the brand,

- Diffuse positioning: frequent changes in the positioning strategy may create confusion among buyers,

- Ambiguous positioning: a brand that offers too many advantages may be subject to suspicion.

Kotler $^{6}$ structured the positioning possibilities into seven positioning strategies. Each strategy concentrates on one of the following:

- Attributes (characteristics of the product that render it superior as compared to similar products),

- Advantages (for the customer),

- Usage (why the usage of the specific product has more benefits than a similar product),

- Consumer (what type of consumer does the brand address),

- Competition (why does the consumer choose the product instead of going to the competition),

- Quality or price (quality/price ratio).

Brand positioning provides the platform to move the brand along its path to the aspirational identity and provides the foundation of all external communications.

In developing a brand's positioning strategy, it is time to think succinctly about whom the brand is intended to reach, with what offerings, what benefits the brand provides and how those benefits are superior to or at least diffentiated from the competition.

\subsection{Communicating Your Brand's Positioning - Advertising Slogan versus Positioning Statement}

This is the moment when the position adopted by the company must be made public. The ultimate scope of questions like: Where does the company deliver maximum value? What is the thing that the company does better than any other competitor? What is the position that will take the company or the product ahead of the competition? is to reveal the secret weapon of any positioning strategy - the positioning statement.

The first public whose loyalty must be won over with this statement is the internal one: the company's employees. With a motivated team that understands the direction the company is heading and the things it offers the consumers, the victory over competition is almost inevitable. Thus, internal communication is the first step that must be made in the communication of the adopted position. The next public is, of course, the external one.

But what is the positioning statement after all?

Most of the times, the advertising slogans are confused with the positioning statement. The advertising slogans play an important part in the advertising campaigns. They are titles, headlines with a relatively short life, but with an extraordinary potential. In order to benefit from and exploit this potential, these slogans must be seen from another point of view, namely: ,what is going to happen with the slogan at maturity?”.

There are a lot of examples ${ }^{7}$ of advertising slogans that turned into well-known positioning statements:

\footnotetext{
${ }^{6}$ Kotler, Philip, „The Managementul Of Marketing”

7 Attig, D.Wendal, Blow the Whistle on your Competition, Florida, The Ampersand Publishing Group
} 
„We bring good things to life” - General Electric

„It's the real thing”- Coca-Cola

„No place on Earth has better weather" - The Weather Channel

All the above companies considered the slogan more than a simple etiquette phrase

and adopted a strategic oriented way of thinking. These are the companies that won leading market positions.

In order to do this, the company communicates a differentiation idea or concept that reflects more than their name does. As stated in the first chapter, the brand is the one that promotes the identity of the company to the consumers. This process is carried out by the positioning statement.

In this way, the positioning statements transmit the capacities or the unique intentions of the company, communicate the perspectives of the company regarding its clients or the market. The positioning statement is seen as an investment for the positioning in front of the competition, with the hope that it will have a strategic and long term impact.

The positioning statement contains the brand promise and thus helps the company obtain the desired place in the market. As seen above, it all depends on some well-chosen words and their impact on the mind of the consumer. The positioning statement may have the ability to influence buying decisions and markets.

Evidently, to win the loyalty of the buyers you need more than a statement of values and aspirations; you need a strong sustenance at all the levels of the product. A solid positioning is reflected in all the elements of the marketing mix and evolves in time, adapting to market changes and mission of the brand.

To obtain the desired position, the communicated message must be reflected in all positioning platforms:

1. The first platform - the product itself, must evolve in time and adapt to maintain a high market share;

2. The second platform - the services offered with the product. These are the ones that make the difference between the products. In order to establish a strong brand, it is necessary to take into account the distribution possibilities, for they should be in accordance with the product offered and should insure the accessibility.

Finally, the company's reputation and implicitly the brand's reputation represent a final positioning platform that is very fragile. A reputation built very hard in time can be easily distroyed because a slight negligence or carelessness.

All these positioning platforms must be used in an integrated manner in order to insure the basis of an unbeatable and unmatched brand.

Brand-based communication focuses on the right mix of media vehicles that will maximize the brand's potential to meet the goals set forth in the brand vision. The assumption is that the foundations in place will lead to the appropriate brand supporting communications strategy. It is critical to take an integrated communications approach that links back to the brand vision, Brand Picture, and brand positioning.

The AUTHOR model provides this link. The six steps to the author approach are:

1. Awareness: first, you must create awareness for your brand,

2. Understanding: with awareness achieved, efforts should be geared to helping your customers understand what your brand stands for - its positioning,

3. Trial: after understanding, your communications should focus on inducing customers to try your brand,

4. Happiness: having tried the brand, the customer has a very favourable impression of your brand, 
5. Only one: this stage is crucial - with communications geared toward convincing customers to think about only your brand in your category,

Referral: when customers put their reputation on the line by referring your brand to a peer, you have achieved the ultimate in brand satisfaction.

Brand-based communication vehicles include advertising, Internet promotions, public relations, trade and sales promotion, consumer promotions, direct marketing, event marketing, and internal employee communication. Some are longer-term in nature, others focus on shortterm results. Using a mix of short and long-term vehicles will support a consistent brand message that clarifies the brand promise, while leveraging the vehicle's strengths.

For instance, a typical marketing calendar may include a mix of advertising, consumer promotions, public relations, and sales promotions with each serving a distinct purpose. The advertising campaign may clarify the brand's positioning throughout a year or season, while the consumer and trade promotion concentrate their efforts during a particular sales cycle, say after a car show when new cars are launched each fall. The public relations campaign may focus on getting unbiased, favourable coverage in the press to sway shoppers to a particular brand or informing the target of a new feature that is important to the target.

\subsection{Extending Your Brand}

Another strategy to be incorporated into the overall BAM strategy involves evaluating the boundaries of your brand and determining how far they might be stretched.

Knowing your brand's ability to grow stems directly from its brand identity. Good brand extensions stretch the brand and add to its value as an asset, whether by expanding in the same category or by expanding into logical new categories or new markets.

The following are, in short, what a company can do with a brand once it has been created. Thus, a company has four alternatives to promote its products or services:

\subsubsection{Product Line Extension}

The existing brand name applies to the new components of the existing product category. Many times, the overproduction capacity is the cause that determines a company to create new items.

Nowadays, many companies launch brand alternatives, due to the pressure of the retailers. The reason underlying this strategy is that retailers want to win over the loyalty of the buyers through the known brands, but at a smaller price. The extension implies some risks. First, there is the possibility of a brand losing its initial significance and meaning. Secondly, there is the risk of the new product not selling sufficiently well, and in this way, its commercialization must be supported by other components of the line.

Lately, it looks like producers and distributors reached the conclusion that line extension leads more to income diminishing than to an increase in sales.

\subsubsection{Brand Extension}

This strategy refers to using an existing brand for launching a new item belonging to a new category of products.

Brand extension offers some advantages. A strong brand offers the new product the opportunity for fast recognition and immediate acceptance from the consumers. 
Therefore, the company can more easily launch new categories of products. Moreover, brand extension contributes to advertising cost reduction since the initial brand has already the loyalty of consumers on a specific market segment.

However, this strategy implies some risks. The new product might disappoint the consumers, affecting in this way their impression regarding the initial brand. There is also the possibility of the new product not identifying itself with the initial brand, phenomenon known as brand dilution (the consumer's no longer associate the brand with the product).

\subsubsection{Multiple Brands}

When companies launch new brands for the same category of products, they use the multiple brands strategy. The central reason for this decision is the creation of products with different characteristics or for attracting new customers. Likewise, the company might try to protect its initial brand, by means of creating new defensive brands.

The risk of using this strategy is obtaining a small market share for every launched brand, without any of it being sufficiently profitable. Therefore, the company might get to a point where it has to abandon weak brands in order to concentrate its efforts on the more profitable ones.

\subsubsection{New Brands}

When a company launches a new category of products, it might discover that none of the existing brands identifies with the new product. As stated when talking about the brand extension strategy, this might affect the current image of the company. A new brand may also be launched if the company considers that the existing brand name has a diminishing power.

\subsection{Leveraging Your Brand to Maximize Channel Influence}

Channel management is often a contentious affair, with a constant pull and push between retailers, wholesalers and manufacturers, each vying for leverage. Strengthening your brand offers greater leverage in influencing how the channel performs. Moreover, the power is constantly shifting in the channel game, which requires companies to be nimble in order to change strategy to be successful.

For success, you have to constantly address this question: how do I most effectively get my products and services to my target audience and what role will the brand play in helping me do that?

One way is to reinvent the channel, as Starbucks did by repackaging its offering, focusing on how customers wanted to receive it and consistently investing in brand building, and ensuring that customers had good experiences. These efforts resulted in strong customer loyalty and word-of-mouth growth. Ultimately, they created a destination channel.

For similar success, you must use your brand to maximize the control you have over your channel by playing to five key channel members „hot buttons:

1. High Quality Product. There is no stronger draw than quality as customers will generally pay more for it and will shop elsewhere if their first destination does not have the brand in stock.

2. Education and Training. For both selling the product and in strong post-sale service support, this is important to both the channel member and end customer.

3. A Brand That Is A Drawing Card. The stronger your brand, the more likely that channel members will want to be connected to it. 
4. A Reasonable Pricing Strategy. The idea is to allow all channel members to get their cut. Since strong brands command higher prices, there are more dollars for all intermediaries.

5. Funding To Help Promote the Brand. The more it appears that both sides are contributing to the final sale, the more likely there will be a strong commitment to sell your brand.

\subsection{Pricing Your Brand at a Premium.}

The Brand Picture helps you determine whether the strength of the brand can support a premium position. Brand loyalty drives your ability to charge a premium price, so you can fully enjoy and leverage the power or your brand. But the trick is to be aware of the gap relative to the competition and manage it consciously. Even with Tide's dominant position in the laundry detergent aisle, it was priced three times the value brand at Target, even though both claimed to offer a bleach alternative. At that premium, Target shoppers - historically value shoppers - might be tempted to try the value brand. With satisfactory performance, Tide may risk permanent brand switching.

\section{Bibliography:}

1. Attig, D.Wendal, „Blow The Whistle On Your Competition”, Florida, The Ampersand Publishing Group, 1998

2. Dobrotă, Nită, Dictionary of Economy, Ed. Economică, Bucharest, 1999;

3. Friedman Rose / Milton, Free to choose, Ed. ALL, Bucharest, 1998;

4. Klenk Jurgen, Philip Cristine Reineke, Ralf Dieter, Schmitz H., Privatisation in developing countries, Ed. Economică, Bucharest, 1997;

5. Kothler, Ph., Marketing Management, TEORA Publishing House, Bucharest, 1997;

6. Kregel Ian, Matzner Egon, Grabher Gernot, The market shock, Ed. Economică, Bucharest, 1995

7. Mill John Stuart, About Freedom, Ed. Humanitas, Bucharest, 1994;

Neguciou Aurel, The reasonable transition, Ed. Economică, Bucharest, 1999; 
